IZA DP No. 5929

Economic Growth and Child Poverty Reduction in Bangladesh and China

Syeda Shahanara Begum

Deng Quheng

Björn Gustafsson

August 2011 


\title{
Economic Growth and Child Poverty Reduction in Bangladesh and China
}

\author{
Syeda Shahanara Begum \\ University of Gothenburg \\ Deng Quheng \\ Chinese Academy of Social Sciences
}

Björn Gustafsson

University of Gothenburg

and IZA

\section{Discussion Paper No. 5929 \\ August 2011}

\author{
IZA \\ P.O. Box 7240 \\ 53072 Bonn \\ Germany \\ Phone: +49-228-3894-0 \\ Fax: +49-228-3894-180 \\ E-mail: iza@iza.org
}

\begin{abstract}
Any opinions expressed here are those of the author(s) and not those of IZA. Research published in this series may include views on policy, but the institute itself takes no institutional policy positions.

The Institute for the Study of Labor (IZA) in Bonn is a local and virtual international research center and a place of communication between science, politics and business. IZA is an independent nonprofit organization supported by Deutsche Post Foundation. The center is associated with the University of Bonn and offers a stimulating research environment through its international network, workshops and conferences, data service, project support, research visits and doctoral program. IZA engages in (i) original and internationally competitive research in all fields of labor economics, (ii) development of policy concepts, and (iii) dissemination of research results and concepts to the interested public.
\end{abstract}

IZA Discussion Papers often represent preliminary work and are circulated to encourage discussion. Citation of such a paper should account for its provisional character. A revised version may be available directly from the author. 
IZA Discussion Paper No. 5929

August 2011

\section{ABSTRACT \\ Economic Growth and Child Poverty Reduction in Bangladesh and China ${ }^{*}$}

This paper analyzes child poverty in Bangladesh and China during periods of rapid economic growth in both countries. It compares the extent as well as profile of child poverty in both countries. Comparisons on the extent of child poverty, over time and across countries, are made using a decomposition framework attributing child poverty differences to differences in the three components mean child income, demographic circumstances and the distribution of child income. Child poverty is found to be more extensive in Bangladesh than in China, and is very much a problem for rural children in both countries. The results show that economic growth can reduce child poverty but does not do so always. For understanding changes over time and across countries in the extent of child poverty, it can be necessary to also consider changes/differences in the distribution of child income as well as in the demographic composition.

JEL Classification: $\quad$ I32, J13, J15

Keywords: $\quad$ child poverty, economic growth, Bangladesh, China

Corresponding author:

Björn Gustafsson

Department of Social Work

University of Gothenburg

P.O. Box 720

SE 40530 Göteborg

Sweden

E-mail: Bjorn.Gustafsson@socwork.gu.se

\footnotetext{
* An earlier version of the paper was presented at the International Conference on Experiences and Challenges in Measuring National Income and Wealth in Transition Economies, September 19-21, 2007, Beijing, China, jointly organised by the International Association for Research on Income and Wealth (IARIW) and the National Bureau of Statistics (NBS), China.
} 


\section{Introduction}

This paper describes child poverty in Bangladesh and China and investigates reasons for changes over time as well as differences across the two countries. Following an often used, but not uncontroversial alternative, we define a child as poor if as living in a household that has a disposable income of less than one dollar a day in Purchasing Power Parities. We use large sample surveys. For Bangladesh we study the period 1995/1996 to 2000, for China the period 1988 to 1995 as well as the period 1995 to 2002. Child poverty is compared across time and across the two countries. This is done using a decomposition framework by which poverty differences are attributed to differences in the three components mean child income, demographic composition and the distribution of child income.

There is consensus among observers of the desirability of combating child poverty; it has become a subject of great interest among policymakers and researchers alike. However, concerns about child poverty have been more forcefully expressed in richer countries and in the Commonwealth of Independent States than in low- and middle-income countries. ${ }^{2}$ We are not aware of any previous effort to compare the extent and evolution of child poverty across Asia or across low- and middle-income countries, which forms the first motivation for this study.

A second motivation is that the question of how economic growth affects poverty is open for debate. This paper adds to the literature on growth and poverty reduction by providing two case examples. Studying two growing Asian countries yields more knowledge than by investigating merely one. Bangladesh during the second part of the 1990s is one of the cases, and the other is the People's Republic of China from the late 1980s to the beginning of the new millennium. China's amazing growth record of the last 30 years stimulated by a policy of opening up is well known. However, starting from a lower level, Bangladesh recently has experienced rapid economic growth as well. In addition to comparing the two countries as entities, we also compare Bangladesh with the southwestern region of China. The reason for this is that China is characterised by large regional differences in levels of income. The southwestern region of China, with a considerably lower than average income level, is in this respect as well as in location more similar to Bangladesh than other parts of China.

\footnotetext{
${ }^{2}$ The United Nations Children's Fund (UNICEF) monitors child poverty in rich countries, Southeastern Europe and the Commonwealth of Independent States (Corak, 2006; UNICEF, 2007). Contributions to the academic literature on child poverty include Bradbury et al. (2001), Vleminckx and Smeedinged (2001), Gordon et al. (2003) and Corak et al. (2008).
} 
Comparing Bangladesh with southwest China thus provides another investigation of how economic growth affects child poverty.

The supposition that economic growth is a prerequisite for poverty reduction in a longer time perspective is not without controversy. ${ }^{3}$ Disagreements stem from economic growth being the outcome of many different processes. Growth is not necessarily distributionally neutral; it can be concentrated to those worse off, or to those better off. In case economic growth is concentrated to those worse off income inequality as well as poverty decreases while if growth is concentrated to those better off inequality increases and poverty may or may not decrease.

One reason for rapid economic growth in the developing world during recent years has been the opening up of previously more closed economies to allow for increased international trade and foreign investment. If leading to rapid industrialisation, such processes can benefit domestic capital owners as well as skilled and semi-skilled urban workers. However, this type of growth does not necessarily spill over immediately to rural areas where typically most of the country's poor reside. This is why there can be episodes where positive economic growth in the economy does not go hand in hand with poverty reduction in the population. ${ }^{4}$ Episodes of no poverty reduction despite economic growth can also be the result of demographic changes (widely defined). If ever larger/smaller proportions of the population belong to greater/lesser poverty-prone segments, this counteracts/reinforces impulses towards poverty reduction coming from a growing economy.

Given that growth and poverty reduction must not necessarily go hand in hand, it is not surprising that questions of the connection between economic growth and poverty reduction are subject to considerable research efforts. Different countries and periods have been investigated using various research strategies. There are studies analysing single countries and others analysing many countries. ${ }^{5}$ However, to our knowledge there is no previous study focusing as here on how economic growth affects the extent of poverty among children.

\footnotetext{
${ }^{3}$ That is, when "poverty" is defined as living under a predetermined fixed poverty line ("absolute poverty"). When "poverty" is defined as living under a poverty line representing a poverty line that is updated to the general level of living ("relative poverty"), one cannot assume that economic growth leads to less "poverty". ${ }^{4}$ Winters et al. (2004) survey the literature on trade liberalization and poverty.

${ }^{5}$ One example of the former is Thurlow and Wobst (2006) who apply a general equilibrium and micro-simulation model to examine how the sectoral structure of growth in Zambia affects poverty, and find that not all growth is equally good for the poor. Among macrostudies, Dollar and Kraay (2002) is often quoted. Kraay (2006) applies a decomposition framework to analyse data mainly from the 1990s covering 80 developing countries in which
} 
In this study child poverty is defined as living in a household with a disposable income lower than the often used international poverty line of one-dollar-a day promoted by the World Bank. Turning to our results, it is hardly surprising that for any given point in time, child poverty has been more extensive in Bangladesh than in China. During one of the three spells of rapid economic growth studied, child poverty did not decrease profoundly in China. Here, a more unequal distribution of child income between 1988 and 1995 offset the poverty-reducing impulses of economic growth. However, for the other two spells studied, economic growth was in step with child poverty reduction; this was the evolution in Bangladesh for 1995/1996 to 2000 as well as for China from 1995 to 2002.

The cross-country comparisons show that the lower child poverty rates in China can mainly be attributed to the country's higher average child income level, while differences in income inequality and demographic composition are of lesser importance. When trying to understand why in the mid-1990s southwest China had lower child poverty rates than Bangladesh, we find that differences in demographic composition are fundamental. In southwest China, children lived in families with fewer children than in Bangladesh. However, a few years later, the gap in child poverty between southwest China and Bangladesh had widened with differences in mean child income playing a larger role.

Our study thus illustrates that economic growth and differences in income levels affect child poverty differences across time and across countries. However, it also shows that economic growth does not automatically lead to less child poverty. For understanding changes over time and across countries in child poverty, it can be necessary also to consider changes/differences in the distribution of child income as well as in the demographic composition.

The rest of the paper continues as follows: The next section provides information on the context for the comparison by giving information on the two countries. The data sets used are introduced in Section 3 while we describe child poverty in China and Bangladesh in Section

poverty is defined using the World Bank's “one-dollar-a-day” poverty line. An analysis of spells of poverty change leads to the conclusion that cross-country differences in growth, especially in the medium- and long run, are the dominate factors explaining changes in poverty. Combining this database of poverty spells with information on sector value added and on global trade, Loayza and Raddatz (2010) investigate how the sector composition of growth affects the economy's capacity to reduce poverty. It is concluded that growth in sectors intensively using unskilled labour has the largest potential for reducing poverty. Montalvo and Ravallion (2010) analysed how GDP from primary, secondary and tertiary sectors in China has affected poverty using provincial data from the first part of the 1980s to 2001. Their results support the view that the primary sector (mainly agriculture) has been the main driving force in poverty reduction. Please note that during the spells studied here, the agriculture sector in China grew more slowly than the industrial sector. 
4. The accounting framework is presented in Section 5, and the results from applying it are shown in Section 6. Finally we sum up the study in Section 7.

\section{Context}

When trying to understand the extent and changes of child poverty in Bangladesh and China during the 1990s, some cross-country differences easily come to mind, see Table 1. GNI per capita is higher in China and life expectancy at birth longer. Growth has been more rapid in China, thus further widening the income gap between the countries. However, the distribution of income/consumption is less unequal in Bangladesh. Furthermore, Table 1 shows that the age structure of the populations differs markedly. Children make up a larger proportion of the total population in Bangladesh. China has reached a further stage in the process of demographic transition with a lower birth rate and under-age-five mortality rate. These developments are consistent with the adoption of China's one child policy and Bangladesh's policy of encouraging no more than two children.

/Table 1 about here/

Furthermore, although a process of rapid urbanisation is taking place in both countries, the majority of people in Bangladesh and China still live in rural surroundings. Yet, the countries differ in one important aspect regarding the dimension rural-urban. The People's Republic of China introduced the Hukou system in the 1950s, a system with no counterpart in Bangladesh. The Hukou system categorises people and only those classified as urban residents had the right (at that time) to live in a city. The development policy adopted soon after PR China was formed was meant to prioritise the better-off urban population. Rural households had to deliver quotas of agricultural products thereby funding the industrialisation that took place in urban China. ${ }^{6}$ As a consequence, the urban to rural income gap is larger in China than in many other countries. The Hukou system has functioned as a barrier to movements of the less-privileged rural inhabitants into the cities. As a consequence, China has long had very little mass poverty within its registered urban population. ${ }^{7}$ The situation is not the same in

\footnotetext{
${ }^{6}$ See for example Knight and Song (1999) and Whyte (2010). Sicular et al. (2007) attribute about half of the contemporary rural to urban income gap to differences in endowments, most importantly education. For recent changes in the Hukou system see Chan and Buckingham (2008).

${ }^{7}$ However, a new kind of poverty has appeared in the cities of China. One explanation for this is the inmigration of rural residents who do not have an urban Hukou. Another explanation is the policy of economic restructuring that appeared in China during the latter part of the 1990s and its consequences. This has led to increased unemployment and decreased labour market participation. When assessing poverty in urban China,
} 
Bangladesh's cities where big cities in particular have experienced large population influxes due to expectations of more rapid development of employment opportunities.

Despite Bangladesh belonging to the group of the ten most populous countries in the world (a list headed by China), China has a population nine times as large. Bangladesh's territory is much smaller than China’s as well. Of China’s 31 province level units, Liaoning (144 900 sq $\mathrm{km}$ ) of northeast China has an area similar in size to Bangladesh (World Bank 2007a). Within China, regions differ considerably regarding economic development. The eastern region is most developed, while the western region, particularly its southern part, is lagging behind. With an average income level and a population size more closely resembling that of Bangladesh (see Table 1), and in addition being situated closer to Bangladesh, it seems motivated to compare child poverty and its development in Bangladesh also with its counterpart in southwest China.

\section{Data}

For studying child poverty in Bangladesh, microdata from household surveys conducted by the Bangladesh Bureau of Statistics for the years 1995/96 and 2000 was used. A two-stage stratified random sampling was used for both surveys. In the first stage 252 rural and 190 urban Primary Sampling Units (PSUs) were selected from the sample frame with probability proportional to size. The PSUs were chosen from 14 different strata (5 rural and 9 urban). At the second stage households were selected from each PSU. The Household Income and Expenditure Survey (HIES) 2000 used almost the same sample design as the Household Expenditure Survey(HES) 1995 with slight modifications (see also Bangladesh Bureau of Statistics, 2003). ${ }^{8}$ Both surveys cover rural as well as urban areas. From the microdata we define three regions which differ in their distance to the coast as well as economic development (Rahman and Hossain, 2009). For this we use the administrative divisions as building block: The most developed coastal or southern region consists of Chittagong, Barisal

poverty lines higher than one-dollar-a-day are usually used, see Riskin and Gao (2010) and Appleton et al. (2010).

${ }^{8}$ The modifications were made in Statistical Metropolitan Areas and PSUs, however, sample sizes were kept the same for both surveys. Also, the definitions for rural and urban were the same in both surveys. Due to the changes in questionnaires some variables needed to be defined as closely as possible, for example, household income, parents of the children, etc. 
and Khulna, the mid-central region of Dhaka and Sylhet, and the less developed inland or northern region of Rajshahi.

The Chinese data come from the three waves of the China Household Income Project (CHIP) survey conducted in 1989, 1996 and 2003 for the reference years 1988, 1995 and 2002. This means we have access to surveys on both rural and urban areas. The 1988 rural survey covers 28 provinces (see Eichen and Zhang, 1993), while nine were not retained in the 1995 survey. These same provinces and also Guangxi and Xinjiang appear in the 2002 survey. The 1988 urban survey was drawn from 10 provinces to represent the Coastal, Central and Western provinces and the same territories were also surveyed in 1995 and 2002 with the addition of Sichuan for the later two years. ${ }^{9}$

The age at which a person is no longer regarded as a child depends on social circumstances that might vary across countries. We choose here to define a child as being age 14 and under. ${ }^{10}$ In Table 2 we report the number of children and adults (as defined above) in our five samples and their sub-samples. There are in total around 16000 children in the two samples for Bangladesh and in the Chinese sample for 1995. The larger size of the Chinese sample of 1988 is partly due to sampling and partly due to birth rates being higher previously. The fall in birth rate in China is also the reason for the Chinese sample of 2002 not having more than 9 000 children. The two later sub-samples for southwest China comprise about 2000 children.

\section{/Table 2 about here /}

Children make up 42 percent of all persons in Bangladesh in the sample for 1995/96 and 39 percent of the sample for 1999/2000, see Table 2. For China the corresponding proportions are much lower, starting at 25 percent in 1988 and falling to 16 percent in 2002. In both countries, at any point in time, children make up a somewhat larger share in rural areas than in urban areas. Children make up a slightly higher population share in southwest China than in China as a whole.

/Table 3 about here/

\footnotetext{
${ }^{9}$ Sichuan was split into two administrative regions at the provincial level, Sichuan and Chongqing, in 1997, both of which are surveyed in our 2002 rural data. For further details on the 1995 and 2002 surveys see Li et al. (2008).

${ }^{10}$ In both countries, children start school at age 6 or 7 . Primary school is typically for 5 or 6 years in China and 5 years in Bangladesh, while junior high school is for 3 years.
} 
In Table 3 we provide descriptions of the five samples and their sub-samples using selected variables. For Bangladesh, we report rural and urban sub-samples and for China only the rural sub-sample; as reported in the next section, poverty as defined in this study is virtually absent within the urban sub-sample for China. Based on earlier writings on gender bias among children in China, ${ }^{11}$ it comes as no surprise that the ratio between boys and girls is higher in China than in Bangladesh, and it actually increases across the surveys. Most children in China are seven to fourteen years of age, while such dominance of school children is less pronounced in Bangladesh. Around ten percent of children in the countrywide samples for China belong to ethnic minorities and in southwest China about one out of three. In contrast, the child population of Bangladesh is rather homogeneous when it comes to ethnicity. ${ }^{12}$ Most children in Bangladesh live in a household including at least three children, while this is unusual in China. In Bangladesh there is not much difference in parental education between rural and urban areas, while the opposite is the case in China where rural parents have considerably lower educations. The table does not indicate any dramatic differences in education level between parents in rural Bangladesh and rural China. ${ }^{13}$

\section{Describing child poverty}

How to define and measure poverty in cross-country comparisons is not self-evident. For some time the World Bank's one-dollar-a-day in Purchasing Power Parity poverty line has been in wide use when assessing poverty on a global scale, for example, in the influential World Development Reports regularly published by the World Bank. The justification for this level is that it stands for a poverty line typically in use in poor countries (see Ravallion et al., 1991). We convert the poverty line into local currencies using available conversion factors. For Bangladesh this means that the poverty line is set to Tk. 404.71 in 1995/96 and Tk. 500.16 in 1999/2000 per person per month. ${ }^{14}$ For China, the poverty line is set to 425 Yuan per year in 1988, 934 Yuan per year in 1995 and 1010 Yuan per year in 2002 in rural China. ${ }^{15}$ The poverty line is set to 450 Yuan, 1025 Yuan, and 1134 Yuan in corresponding years for

\footnotetext{
${ }^{11}$ See, for example, Johansson and Nygren (2001).

${ }^{12}$ As only a very small number of children are classified as an ethnic minority group in the surveys, we do not report the fraction.

${ }^{13}$ As school systems are not the same in the two countries it is not easy to compare education levels.

${ }^{14}$ We compute 1 USD poverty line for the year 2000 as follows:

(U.S. Consumer Price Index in 2000/ U.S. Consumer Price Index in 1985) *[Official Exchange Rate (Tk / USD in 2000)] x Purchasing Power Parity Conversion factor to the official exchange rate. That is 1 USD PPP = $(168.8 / 105.5) * 52.1 * 0.2=16.672$ Taka per day, which is equal to 500.16 Taka per month. The poverty line for 1995 was obtained by deflating with Consumer Price Index for Bangladesh.

${ }^{15}$ Personal communication on the poverty line in 2005 with Shaohua Chen at the World Bank.
} 
urban China. A child is defined as poor if living in a household with a disposable per capita income lower than the poverty line specified.

This is not the only possible alternative for performing cross-country comparisons of child poverty. Yet its advantage is that for some time it has been the alternative most widely used. Reddy and Pogge (2010) have put forward a detailed critique of the approach, and for an answer to this critique see Ravallion (2010). Using more recent data, Ravallion et al. (2009) revise the methodology for defining the poverty line and propose a World Poverty line set to 1.25 USD PPP and day. Based on this, Chen and Ravallion (2010b) present estimates of world poverty 1981-2005 for poverty lines set to USD 1.00, USD 1.25 and USD 2.00. Another subject of discussion is the issue of appropriate conversion factors. For example, new (though not necessarily ideal) conversion factors for China have been derived, leading to revisions of time series of poverty in China (Chen and Ravallion, 2010a). This means if consensus on a new international poverty line including appropriate conversion factors emerges, it would be motivated to revise the results presented here to see how robust they are.

The national poverty line of Bangladesh is different from and not comparable with the poverty line we use for Bangladesh, since the national poverty line is consumption based and higher for both years (see BBS, 2003). For China our poverty line is higher than the poverty line used when the National Bureau of Statistics of China reported the extent of poverty in rural China for the years studied here. However, more recently NBS has adopted a lowincome line that is closer to the one-dollar-a-day poverty line. ${ }^{16}$

\section{/Table 4 about here/}

We report child poverty rates for Bangladesh and China and the sub-samples in Table 4. In the table we split the samples (when relevant) by age, ethnicity, number of children, parental education and region. Table A1 in the Appendix provides corresponding information for the composition of child poverty. First looking at the total samples in Table 5 (in Section 6), we find that child poverty rates in Bangladesh fell from 38 percent in 1995/96 to 28 percent in 2000. In China the child poverty rate was considerably lower, 20 percent in 1988, but had remained almost unchanged in 1995. However, in 2002 the child poverty rate in China was down to 7 percent. When observing the two countries as whole units we have thus found that

\footnotetext{
${ }^{16}$ In 2008, after the period here studied, the National Bureau of Statistics introduced a new poverty line for urban China set to 1196 Yuan per person and year, a level higher than the low-income standard in use, and much higher than the poverty line that had been previously in use.
} 
economic growth and poverty reduction have moved in tandem during two of the spells studied, but much less so during a third (China from 1988 to 1995). Not surprisingly, child poverty rates are higher in Bangladesh than in China.

Virtually all poor children in China live in rural areas and the child poverty rate in urban areas is more or less zero. For urban Bangladesh on the other hand, we report a child poverty rate of 15 percent in 1995/96, and it was only marginally reduced in 1999/2000. In contrast, child poverty rates in rural Bangladesh fell from 47 percent in 1995/96 to 34 percent in 1999/2000. For China, changes in child poverty rates in the country as a whole are entirely driven by child poverty reductions in rural areas. ${ }^{17}$ At the beginning of the new millennium child poverty rates in rural southwest China were of about the same magnitude as in urban Bangladesh, thus lower than in rural Bangladesh.

Child poverty rates are generally a few percentage units higher among the youngest children than among school-aged children. In the samples for China as a whole and for the southwest region, child poverty rates are higher for ethnic minorities than for the majority. A general pattern is found of child poverty rates being highest in families with many children. There is a strong negative relation between parental education and child poverty rates in the data for Bangladesh, whereas a slightly weaker counterpart is found in the later surveys for China. In both countries child poverty rates are highest in the inland regions, lowest in the coastal.

\section{A framework for making poverty comparisons}

We apply a decomposition framework for poverty comparisons attributed to Danziger and Gottschalk (1995). In this accounting framework, poverty differences between situations A and $\mathrm{B}$ are due to three components: differences in average income, differences in demographic composition and differences in the distribution of income. This framework can be used to study changes in poverty over time in a single country, but also to study differences in poverty at one point in time across two countries. The decomposition attributes changes / differences to changes / differences in the three components average child income, the composition of the population under study and the distribution of child income. The framework was first used to study the evolution of poverty in the United States (see Danziger

\footnotetext{
${ }^{17}$ We report an increase in the child poverty rate in rural southwest China from 29 percent in 1988 to 40 percent in 1995, but note that it is based on a relatively small sample and other poverty indices (reported below) do not show an increased extent of poverty.
} 
and Gottschalk, 1995 and Iceland, 2003), and (for some unknown reasons) seems not to have been widely applied to low- and middle-income countries previously.

The general idea of the framework is to quantify how child poverty would have differed as a result of three separate forces: income differences, demographical differences and distributional differences. As further explained below, the first of these shows how the extent of child poverty would have differed due to income growth only. The second shows how child poverty would differ in the case of differed demographic composition only. This component is typically not present in studies of how economic growth in developing countries affects poverty, and can be deemed to be an advantage of the approach. The third component shows how the extent of child poverty would have differed in the case of unchanged average child income, but where the distribution of child income changed between the two situations compared.

The decomposition builds on several steps, beginning with computing the growth component. Starting from an actual base distribution (A), we assign each child an income based on the assumption that the difference in average child income observed between distributions $\mathrm{A}$ and B is equally shared within the population. From this distribution we compute the extent of child poverty. This simulation maintains the demographic composition and income inequality of distribution A, but has the mean child income of distribution B. The first simulation allows us to estimate what every demographic group's child poverty would have been in the second situation if only mean child income differed.

The next step weights these group-specific child poverty indices by demographic composition of the child population as it was observed in distribution B. This second simulation incorporates the inequality of the base situation, but has the mean child income and demographic composition of the second situation. The difference between child poverty from the two simulations equals the difference in child poverty due to demographic differences. When applying this framework we must choose along which variables demographic composition should be defined. In this application we choose to use parental education along with the number of children in the household as these characteristics are shown to affect child poverty rates.

The difference in child poverty that is accounted for by differences in inequality in child income is computed as a residual from the outcome of the second set of simulations and the 
real situation. By construction, the sum of these three components (the difference attributable to differences in mean child income, to demographic differences and to differences in child income inequality) will equal the observed differences in child poverty.

When applying this framework we compute not only the poverty rate, but also other poverty indices belonging to the family of indices proposed by Foster et al. (1984). This means we are not solely assessing child poverty by number affected ("incidence”) $\mathrm{FGT}_{0}$ - the head count ratio, but when using the index $\mathrm{FGT}_{1}$ indices we incorporate how poor the poor are on average ("intensity”). When applying $\mathrm{FGT}_{2}$ we also consider how the poverty deficit (up to the poverty line) is distributed among the poor children (“inequality”).

\section{Results}

/Table 5 about here /

The extent of poverty measured by FGT indices are reported in Table 5 for the samples as well as the various sub-samples. ${ }^{18}$ By measuring poverty by not only the poverty rate, a more nuanced picture of differences can be obtained than by relying solely on the head count index. Thus we find that different indices give different views on how the extent of poverty developed in urban Bangladesh from 1995/1996 to 1999/2000, and that not all indices indicate an increase in poverty in southwest China as a whole between 1988 and 1995.

\section{/Table 6 about here/}

We will first report results of the decomposition illuminating change over time in each country, Table 6. Starting with Bangladesh we find that economic growth was a rather strong force for poverty reduction in the rural region, but rather weak in the urban region. This is not surprising as Bangladesh experienced rapid agricultural growth during the period studied, as discussed in several studies. For example ADB (2001) reports a more than five percent annual growth in agricultural production value for the years 1997 to 2000 (as opposed to a growth of two percent per year during the years 1991 to 1996). Many factors are deemed to have contributed to this development: expansion of the rural non-farm sector, expansion of micro credit programs, and reform of agricultural and other sectors (see also World Bank, 2005).

\footnotetext{
${ }^{18}$ When doing this, we normalise each poor household's poverty gap by its poverty line so it takes values from 0 (as we do not allow for negative incomes) to 1. Thus the average poverty gap (as well as its square) is a positive number lower than 1 .
} 
Indications of change in income inequality are found to be small in rural areas, and their signs differ by poverty indices, as in urban Bangladesh. Demographic change was found to be of very small importance for poverty development in Bangladesh.

Turning to China, and starting with the period 1988 to 1995 we find that increased parental education and fewer children per household worked towards decreased child poverty, but the movement towards poverty reduction from economic growth was considerably more forceful. ${ }^{19}$ However, a worsening of the income distribution was working in the other direction, particularly when assessing poverty by the head count ratio, though less so when applying the distribution sensitive poverty index. Strong growth in average household income in China from 1988 to 1995 did not do much to improve the situation of the poor children in China, a finding that can be traced back to the sectors in which growth appeared. Economic growth was fastest in the eastern part of the country and less impressive in the western part where the highest poverty rates were found.

During the period 1995 to 2002, decreased numbers of children per household continued to work towards less child poverty in China. However, the magnitude of this effect is marginal compared to the poverty-reducing impulses that came from economic growth. Such impulses were somewhat larger than during the preceding period. Increased income inequality did not forcefully counteract the development towards less child poverty as it did in the first period. This means that when summing up the development over the two periods (that is when analysing the period 1988 to 2002), we find that the development of child poverty is to a large extent driven by economic growth, slightly reinforced by demographic change, but also somewhat counteracted by a worsening income distribution.

\section{/Table 7 about here/}

We now ask the question: Why is child poverty less extensive in China than in Bangladesh? Table 7 showing the decomposition results for the mid-1990s and the late-1990s provides some insight and the answer differs somewhat between the two comparisons. However, in both cases the main reason for child poverty being less extensive in China is a higher mean income. Demographic differences contribute to this, particularly in the comparison made for the mid-1990s. Differences across countries in the income distribution work towards reducing

\footnotetext{
${ }^{19}$ Results for rural China reported in Table A in the Appendix are not surprisingly similar.
} 
the cross-country poverty disparity. This is particularly the case when comparing poverty of the mid-1990s.

/Table 8 about here/

When comparing poverty in Bangladesh with poverty in southwest China in the mid-1990s, the importance of demographic differences stands out. At that time, child poverty was clearly less extensive in southwest China than in Bangladesh. However, the decomposition indicates that if southwest China would have had the same demographic composition as Bangladesh (primarily having the same average number of children), there would have only been a slight difference in child poverty rates. ${ }^{20}$ But when making comparisons at the beginning of the new millennium the situation is different. The higher mean income in southwest China is the predominant explanation for poverty being less extensive in southwest China.

Our decomposition analyses have shown that all three components considered are of importance for the poverty comparisons. Rapid economic growth has large potential for lowering the extent of poverty, but it is not sufficient for reducing child poverty. This is a conclusion well in agreement with what can be found in the literature on growth and poverty in the developing world. ${ }^{21}$ Our results also indicate that for poverty comparisons, differences in demographic compositions can be of importance, a possibility typically not considered in the same literature. ${ }^{22}$

\section{Conclusions}

\footnotetext{
${ }^{20}$ However, poverty measured by other indices would have been smaller in southwest China, see Table 8.

${ }^{21}$ For example Ravallion (2001 p 1812) concludes: "The poor typically do share in the benefits of rising aggregate affluence, and they typically do suffer from economic contractions. But there is a sizable variance around the 'typical' outcomes for the poor.” Similarly Bigsten and Shimeles (2007) in an exercise of asking if Africa can reduce poverty by half by 2015, find that while strong focus on growth is the only viable option for some countries, changes in income distribution can have a large effect on poverty in others.

${ }^{22}$ When studying poverty in the United States 1949 to 1999 for different groups using the same framework as that used here, Iceland (2003) found that income growth explains most of the trend in poverty. Rising inequality in the 1970s and 1980s was especially important in explaining increases in poverty among Hispanics, whereas changes in demographic (family) structure played a significant role for children and African Americans through 1990. However, changes in demographic (family) structure no longer had a significant association with trends in poverty for any group in the 1990s.
} 
In this paper we have described child poverty in Bangladesh and China as well as investigated reasons for differences across the two countries using harmonised microdata. We have also investigated reasons for changes over time during periods of rapid economic growth in both countries. The study is based on large samples and a poverty line set to one USD per day. True, this is not the only alternative of defining poverty in cross-country studies. We are aware that in the future the foremost approach could be one in which the international poverty line is set to 1.25 USD per day and that the issue of how to convert this into local currencies will be solved somewhat differently than the method used in this paper. The comparisons of child poverty were made using a decomposition framework according to which poverty differences are attributed to differences in mean child income, demographic differences and differences in the distribution of child income.

Child poverty is very much a problem for rural children in both countries. Not surprisingly we have reported that child poverty is more extensive in Bangladesh than in China. Out of the three spells of rapid economic growth studied, child poverty was found to have decreased profoundly during two spells, while much less during a third (China from 1988 to 1995). A more unequal distribution of income in China between 1988 and 1995 largely offset the poverty reducing impulses coming from economic growth. However, in Bangladesh from 1995 to 2000 and in China from 1995 to 2002, economic growth was much in tandem with child poverty reduction.

A pattern of child poverty rates being highest in families with many children was found in both countries. Child poverty is negatively related to parental education level in Bangladesh and in China in the mid-1990s and thereafter, but much less so than in 1988. Ethnic minority children are more poverty prone than the majority in China, while the Bangladeshi population is more ethnically homogeneous as are the groups of poor children.

The cross-country comparisons show that the lower child poverty rates in China can mainly be attributed to a higher average child income level than in Bangladesh. When trying to understand why in the mid-1990s southwest China had lower child poverty rates than Bangladesh, it was found that differences in demographic composition are central. In southwest China children lived in families with fewer other children than in Bangladesh. However, a few years later, the difference in the extent of poverty between southwest China and Bangladesh had widened and was now driven by differences in mean income. 
Our study thus illustrates that economic growth and differences in income levels are significant for child poverty differences over time and across countries. However, it also shows that economic growth does not by necessity lead to a lessening of child poverty. Similarly, differences in mean income are not the only factors that affect poverty differences across countries. In addition to economic growth, changed distribution of income as well as changed demographic composition can affect how poverty develops. 


\section{References}

ADB (2001) "Rural Development Priorities for Poverty Reduction in Bangladesh. Bangladesh”. Bangladesh Resident Mission, Dhaka. Asian Development Bank. Available at:www.adb.org/documents/epps/ban/rural_development/rural_development.pdf

Appleton, S., Song, L. and Xia, Q. (2010) "Growing out of Poverty: Trends and Patterns of Urban Poverty in China 1988-2002”, World Development, 38, 665-678.

Bangladesh Bureau of Statistics (2003) "Report of The Household Income \& Expenditure Survey, 2000”. Dhaka: Bangladesh Bureau of Statistics.

Bigsten, A and Shimeles, A (2007) “Can Africa Reduce Poverty by Half by 2015?” Development Policy Review, 25, 147 - 166.

Bradbury, B. Jenkins, S. P. and Micklewright, J. Eds. (2001)The Dynamics of Child Poverty in Industrialized Countries. Cambridge University Press.

Chan, K. W. and Buckingham, W. (2008) “Is China Abolishing the Hukou System?” China Quarterly, 195, 582 - 606.

Chen, S. and Ravallion, M. (2010a) "China is Poorer than we Thought, But No Less Successful in the Fight against Poverty", in Anand, S., Segal, P. and Stiglitz, J. (Eds) Debates on the Measurement of Global Poverty, Oxford: Oxford University Press.

Chen, S. and Ravallion, M. (2010b) "The Developing World is Poorer Than We Thought, But No Less Successful in the Fight against Poverty", Quarterly Journal of Economics, 125, 4, 1577-1625.

Corak, M. (2006)“Principles and Practicalities for Measuring Child Poverty in Rich Countries”. International Social Security Review, 59 (2), 3 - 31.

Corak, M., Fertig, M. and Tamm, M. (2008) “A Portrait of Child Poverty in Germany”, Review of Income and Wealth, 54, 547-571.

Danziger, S. and Gottschalk, P. (1995) America Unequal, New York: Russell Sage; and Cambridge, MA: Harvard University Press.

Dollar, D. and Kraay, A. (2002)“Growth Is Good for the Poor”. Journal of Economic Growth. Vol. 7 (2002).Issue 3. September. pp: 195-225.

Eichen, M. and Zhang, M. (1993) “Annex: The 1988 Household Sample Survey - Data Description and Availability", in Griffin, K. and Zhao, R. (Eds) The Distribution of Income in China, New York, St. Martin’s Press.

Foster, J. Greer, J, and Thorbecke, E. (1984) “A Class of Decomposable Poverty Measures”, Econometrica, 52, $761-66$.

Gordon, D., Nandy, S., Pantazis, C., Pemberton, S. and Townsend, P. (2003) Child Poverty in the Developing World. Bristol: Policy Press. 
Iceland, J. (2003) "Why Poverty Remains High: The Role of Income Growth, Economic Inequality and Changed Family Structure”, Demography, 40, 499 - 515.

Johansson, S. and Nygren, O. (1991) "The Missing Girls of China - A New Demographic Account”, Population and Development Review, 17, 35 - 51.

Knight, J. and Song, L. (1999) The Rural - Urban Divide. Economic Disparities and Interactions in China, Oxford: Oxford University Press.

Kraay, A. (2006) "When is Growth Pro-Poor? Evidence From a Panel of Countries", Journal of Development Economics, 80, 198-227.

Li, S., Luo, C., Wei, Z., Yue, X. (2008) “The 1995 and 2002 Household Surveys: Sampling Method and Data Description” Appendix in Gustafsson, B. Li, S. and Sicular, T.. (Eds) Inequality and Public Policy in China, Cambridge: Cambridge University Press.

Loayza, N; Raddatz, C. (2010) "The Composition of Growth Matters for Poverty Alleviation”, Journal of Development Economics, 93, 137-151.

Montalvo, J. and Ravallion, M. (2010) "The Pattern of Growth and Poverty Reduction in China”, Journal of Comparative Economics, 38, 2 - 16.

Rahman, M. H. and Hossain, M. S. (2009) "Convergence in Per Capita Income across Regions in Bangladesh”, Bangladesh Development Studies, XXXII, 45 - 60.

Ravallion, M. (2001) “Growth, Inequality and Poverty: Looking Beyond Averages”, World Development, 29, (11) 1803 - 1815.

Ravallion, M. (2010) “A Reply to Reddy and Pogge” in Anand, S., Segal, P. and Stiglitz, J. (Eds) Debates on the Measurement of Global Poverty, Oxford: Oxford University Press.

Ravallion, M., Datt, G. and Van de Walle, D. (1991) "Quantifying Absolute Poverty in the Developing World”, Review of Income and Wealth, 37, 345 - 361.

Ravallion, M., Chen, S and Sangrula, P. (2010) “Dollar a Day Revised”, World Bank Economic Review, 23, 163-184.

Reddy, S. and Pogge, T. (2010) "How Not to Count the Poor" Chapter 3 in Segal, R. and Stiglitz, J. (Eds) Debates in the Measurement of Global Poverty, Oxford: Oxford University Press.

Riskin, C. and Gao, Q. (2010) “The Changing Nature of Urban Poverty in China” in Anand, S., Segal, P. and Stiglitz, J. (Eds) Debates on the Measurement of Global Poverty, Oxford: Oxford University Press.

Sicular, T., Yue, X., Gustafsson, B and Li S. (2007) “The Urban-Rural Income Gap and Inequality in China”, Review of Income and Wealth, 53, 93-126.

Thurlow, J. and Wobst, P. (2006) "Not All Growth is Equally Good for the Poor: The Case of Zambia”, Journal of African Economies, 15, 603 - 625. 
UNICEF (2007) "Child Poverty in Perspective: An Overview of Child Well-Being in Rich Countries.” Innocentil Research Centre, Report Card,7. Available at http://www.uniceficdc.org/publications/.

Whyte, M.K. (2010) One Country, Two Societies. Rural-Urban Inequality in Contemporary China, Cambridge Massachusetts, Harvard University Press.

Winters, L.A., McCullock, N. and McKay, A. (2004) "Trade Liberalization and Poverty: The Evidence So Far”, Journal of Economic Literature, XLII, 72 - 115.

Vleminckx, K. and Smeeding, T. (2001) Child Well-Being, Child Poverty and Child Policy in Modern Nations, Bristol: Policy Press.

World Bank (2003) World Development Report 2003, Washington D.C.

World Bank (2005) “Attaining the Millennium Development Goals in Bangladesh: How Likely and What Will It Take To Reduce Poverty, Child Mortality and Malnutrition, Gender Disparities, and to Increase School Enrolment and Completion?” Report No. 31846-BD.

World Bank (2007a) “China at a Glance”. World Bank. www.worldbank.org/china

World Bank (2011a) World Development Indicators 2011, Washington D.C.

World Bank (2011b) World Development Report 2011, Washington D.C. 
Table 1

A comparison of Bangladesh and China

\begin{tabular}{|c|c|c|c|}
\hline & Bangladesh & China & Southwest China $^{\mathbf{a}}$ \\
\hline \multicolumn{4}{|l|}{ Population, millions } \\
\hline 1990 & 116 & 1135 & 180 \\
\hline 2009 & 162 & 1331 & 197 \\
\hline $\begin{array}{l}\text { Average population growth } \\
\text { 1990-2009, percent }\end{array}$ & 1.8 & 0.8 & 0.5 \\
\hline $\begin{array}{l}\text { Proportion of people aged } 0 \\
-14 \text { years, 2009, percent }\end{array}$ & 31 & $20^{b}$ & 20 \\
\hline Surface, thousand sq km & 144 & 9600 & 2339 \\
\hline $\begin{array}{l}\text { Population density, People } \\
\text { per square km } 2009\end{array}$ & 1246 & 143 & 84 \\
\hline $\begin{array}{l}\text { Purchasing Power Parity } \\
\text { Gross National Income } \\
\text { Per capita USD } 2009\end{array}$ & 1560 & 5490 & $3370^{c}$ \\
\hline $\begin{array}{l}\text { GDP average annual growth } \\
2000-2009 \text {, percent }\end{array}$ & $5.9^{\mathrm{d}}$ & $10.9^{d}$ & $11.0^{\mathrm{d}}$ \\
\hline $\begin{array}{l}\text { Literacy rate adults (\%) of } \\
\text { population } 15 \text { and above, } \\
2009^{c}\end{array}$ & 56 & 94 & 90 \\
\hline $\begin{array}{l}\text { Urbanisation of total } \\
\text { population }\end{array}$ & & & \\
\hline 1990 & 20 & 27 & 13 \\
\hline 2009 & 28 & 44 & 38 \\
\hline $\begin{array}{l}\text { Gini coefficient for income } \\
\text { /consumption 2005, percent }\end{array}$ & 31.0 & 41.5 & N.A. \\
\hline $\begin{array}{l}\text { Under five mortality rate } \\
\text { Per } 1000\end{array}$ & & & \\
\hline 1990 & 148 & 46 & 64 \\
\hline 2009 & 52 & 19 & N.A. \\
\hline $\begin{array}{l}\text { Life expectancy at birth } \\
\text { 2006, years }\end{array}$ & $65^{\mathrm{e}}$ & $73^{e}$ & $68^{\mathrm{f}}$ \\
\hline $\begin{array}{l}\text { Crude birth rate. Per 1000, } \\
2009\end{array}$ & 21 & 12 & 11 \\
\hline
\end{tabular}

Notes:

${ }^{\text {a }}$ Southwest China is here defined to include the following province level units: Sichuan, Guizhou, Yunnan and Tibet. It also includes Chongqing which until 1996 was a part of Sichuan.

${ }^{\mathrm{b}}$ Includes Taiwan.

Source: World Bank (2011a), with exceptions denoted.

${ }^{\mathrm{c}}$ Gross regional product instead of Gross national income is reported as Gross national income for each province is not available.

${ }^{\mathrm{d}}$ Source World Bank (2011b)

${ }^{\text {e }}$ Source http://data.worldbank.org

${ }^{\mathrm{f}}$ Life expectancy at birth in 2000. For China as a whole, life expectancy at birth in 2000 is 71.

Source: China Statistical Yearbook and Provincial Statistical Yearbooks, various issues; China One Per Cent Population Survey 2005 
Table 2. The number of children and adults in the samples for Bangladesh 1995 and 2000 and for China 1988, 1995 and 2002

\begin{tabular}{|c|c|c|c|c|c|c|}
\hline & \multicolumn{2}{|c|}{ All } & \multicolumn{2}{|c|}{ Urban } & \multicolumn{2}{|c|}{ Rural } \\
\hline & Number & Percentage & Number & Percentage & Number & Percentage \\
\hline \multicolumn{7}{|c|}{ Bangladesh } \\
\hline \multicolumn{7}{|c|}{1995} \\
\hline Children & 16569 & 42.43 & 4910 & 38.97 & 11659 & 44.07 \\
\hline Adults & 22482 & 57.57 & 7688 & 61.03 & 14794 & 55.93 \\
\hline Entire & 39051 & & 12598 & & 26453 & \\
\hline \multicolumn{7}{|l|}{2000} \\
\hline Children & 15071 & 39.13 & 4388 & 35.71 & 10683 & 40.73 \\
\hline Adults & 23447 & 60.87 & 7899 & 64.29 & 15548 & 59.27 \\
\hline Entire & 38518 & & 12287 & & 26231 & \\
\hline \multicolumn{7}{|l|}{ China } \\
\hline \multicolumn{7}{|l|}{1988} \\
\hline Children & 30809 & 24.98 & - & - & 13653 & 26.60 \\
\hline Adults & 92517 & 75.02 & - & - & 37682 & 73.40 \\
\hline Entire & 123326 & & & & 51335 & \\
\hline \multicolumn{7}{|l|}{1995} \\
\hline Children & 16090 & 21.54 & - & - & 8160 & 23.49 \\
\hline Adults & 58621 & 78.46 & - & - & 26579 & 76.51 \\
\hline Entire & 74711 & & & & 34739 & \\
\hline \multicolumn{7}{|l|}{2002} \\
\hline Children & 9428 & 15.97 & - & - & 6403 & 17.80 \\
\hline Adults & 49623 & 84.03 & - & - & 29565 & 82.20 \\
\hline Entire & 59051 & & & & 35968 & \\
\hline \multicolumn{7}{|c|}{ Southwest China } \\
\hline \multicolumn{7}{|c|}{1988} \\
\hline Children & 3577 & 27.07 & - & - & 2784 & 28.37 \\
\hline Adults & 9635 & 72.93 & - & - & 7029 & 71.63 \\
\hline Entire & 13212 & & & & 9813 & \\
\hline \multicolumn{7}{|l|}{1995} \\
\hline Children & 2132 & 20.19 & - & - & 1356 & 22.37 \\
\hline Adults & 8426 & 79.81 & - & - & 4706 & 77.63 \\
\hline Entire & 10558 & & & & 6062 & \\
\hline \multicolumn{7}{|l|}{2002} \\
\hline Children & 2082 & 17.44 & - & - & 1498 & 19.82 \\
\hline Adults & 9859 & 82.56 & - & - & 6060 & 80.18 \\
\hline Entire & 11941 & & & & 7558 & \\
\hline
\end{tabular}

Sources: Authors’ calculations from HES 1995, HIES 2000, CHIP 1988, 1995 and 2002. 
Table 3. Samples of children by background characteristics (in percentage)

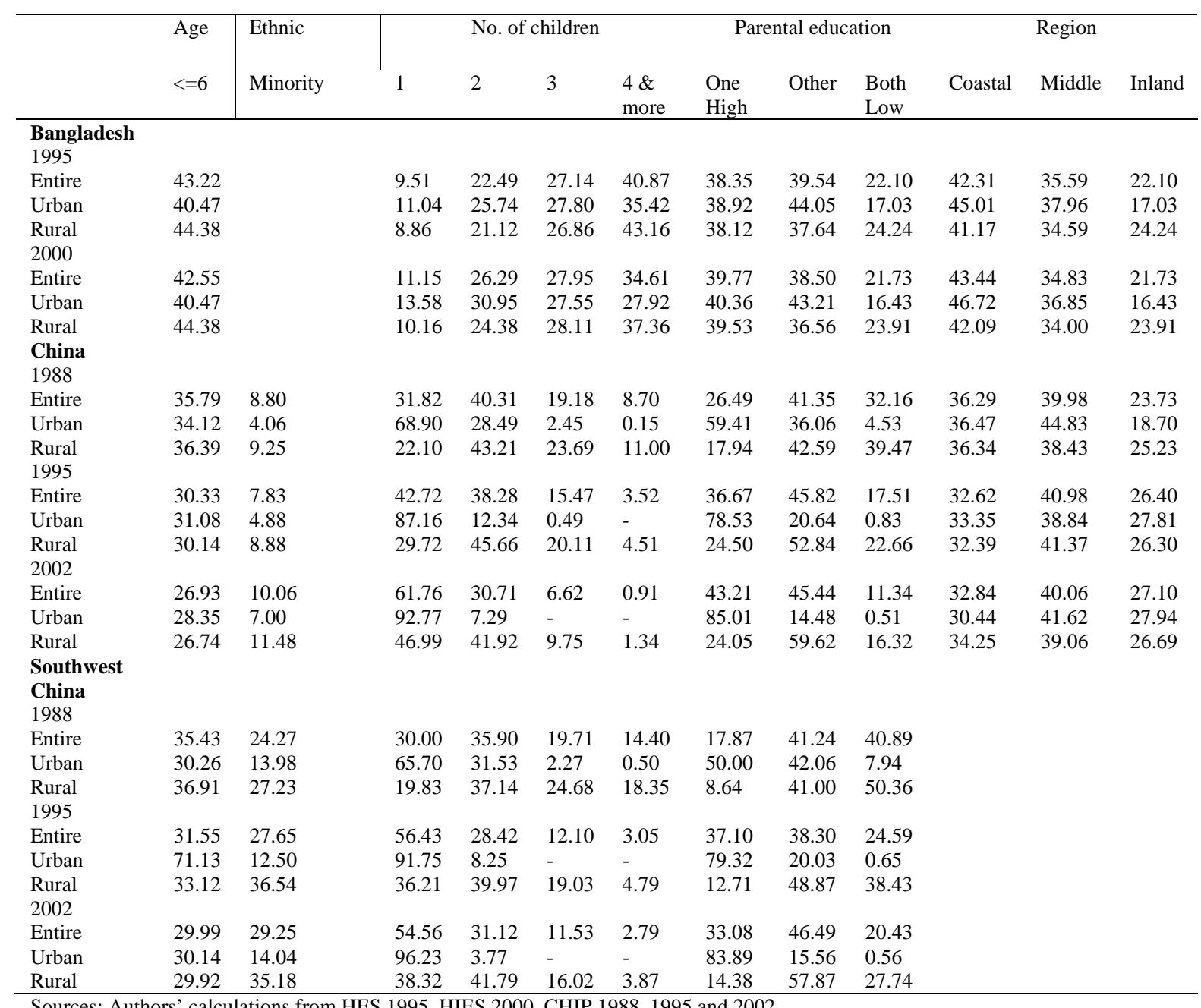

Sources: Authors’ calculations from HES 1995, HIES 2000, CHIP 1988, 1995 and 2002. 
Table 4. Child poverty rates in Bangladesh 1995 and 2000, China and Southwest China 1988, 1995 and 2002 (in percentage)

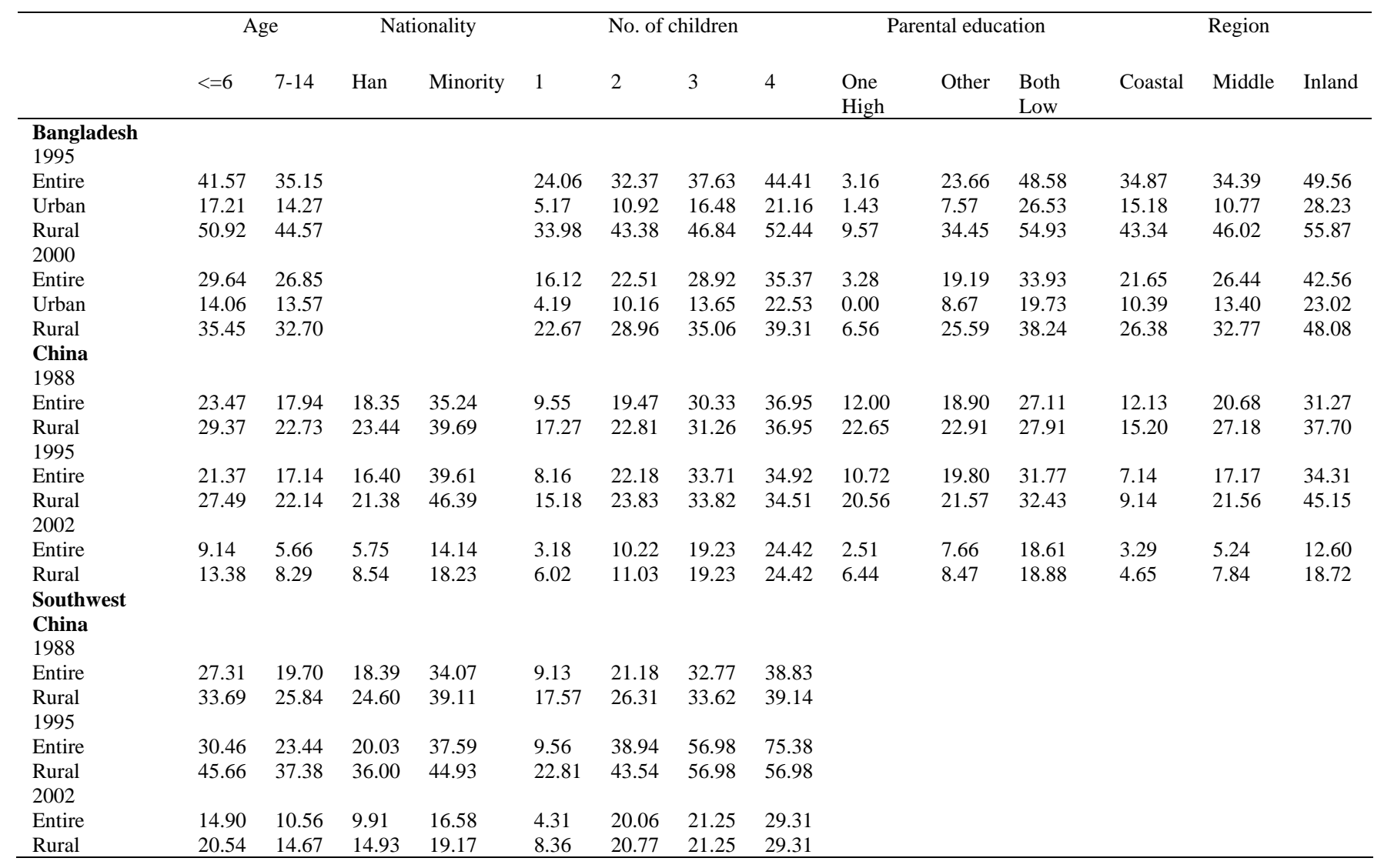

Sources: Authors’ calculations from HES 1995, HIES 2000, CHIP 1988, 1995 and 2002.

Note: The child poverty rates for urban China are less than $0.5 \%$, therefore we do not report breakdowns for urban China in the table. 
Table 5. Foster, Greer, and Thorbecke (FGT) indices of Child Poverty for Bangladesh 1995 and 2000, China and Southwest China 1988, 1995 and 2002 (Percent)

\begin{tabular}{llll}
\hline & FGT(0) & FGT(1) & FGT(2) \\
Rural Bangladesh & & & 0.0719 \\
1995 & 0.4739 & 0.1542 & 0.0527 \\
/2000 & 0.3390 & 0.1059 & \\
Urban Bangladesh & & 0.0143 \\
1995 & 0.1546 & 0.0366 & 0.0182 \\
/2000 & 0.1376 & 0.0381 & \\
Entire Bangladesh & & & 0.0549 \\
1995 & 0.3793 & 0.1193 & 0.0426 \\
2000 & 0.2804 & 0.0861 & \\
Rural China & & 0.0389 \\
1988 & 0.2514 & 0.0785 & 0.0279 \\
1995 & 0.2375 & 0.0665 & 0.0096 \\
2002 & 0.0965 & 0.0232 & 0.0306 \\
Entire China & & 0.0214 \\
1988 & 0.1992 & 0.0619 & 0.0066 \\
1995 & 0.1842 & 0.0512 & \\
2002 & 0.0660 & 0.0159 & 0.0340 \\
Southwest China: (rural) & & & 0.0415 \\
1988 & 0.2874 & 0.0788 & 0.0129 \\
1995 & 0.4012 & 0.1058 & \\
2002 & 0.1642 & 0.0369 & 0.0265 \\
Southwest China: (whole) & & & 0.0265 \\
1988 & 0.2239 & 0.0614 & 0.0093 \\
1995 & 0.2566 & 0.0677 & \\
2002 & 0.1186 & 0.0267 & \\
\hline
\end{tabular}

Sources: Authors’ calculations from HES 1995, HIES 2000, CHIP 1988, 1995 and 2002.

Note: The family of FGT indices, see Foster. Greer and Thorbecke (1984), weights the proportion of persons falling below the poverty line by size of the gap between income and the poverty line. In this application, we set the (exponential) weight equal to 0,1 , and 2 and arrive at the poverty rate, the poverty gap index and the poverty squared index. When calculating FGT(1) and FGT(2) we have first normalized each poor household's poverty gap with its poverty line, so it takes values from 0 (as we do not allow negative incomes) to 1 . Thus the average poverty gap as well as its square is less than 1. 
Table 6. The decomposition of percentage-point change in the poverty rate, Bangladesh 1995 to 2000 and Entire China 1988 to 1995, 1995 to 2002 and 1988 to 2002

\begin{tabular}{|c|c|c|c|c|c|c|c|c|c|}
\hline \multirow[t]{2}{*}{ Bangladesh (1995-2000) } & \multicolumn{3}{|l|}{ Rural } & \multicolumn{3}{|l|}{ Urban } & \multicolumn{3}{|l|}{ Total } \\
\hline & FGT(0) & FGT(1) & FGT(2) & FGT(0) & FGT(1) & FGT(2) & FGT(0) & FGT(1) & FGT(2) \\
\hline Actual change in poverty rate & -0.1348 & -0.0483 & -0.0193 & -0.0169 & 0.0015 & 0.0039 & -0.0989 & -0.0332 & -0.0122 \\
\hline (1) Economic changes & -0.1365 & -0.0471 & -0.0183 & -0.0269 & 0.0006 & 0.0040 & -0.1036 & -0.0330 & -0.0115 \\
\hline (a) Growth in mean adjusted income & -0.1281 & -0.0504 & -0.0249 & -0.0014 & -0.0010 & -0.0004 & -0.0711 & -0.0248 & -0.0120 \\
\hline (b) Change in income inequality & -0.0084 & 0.0033 & 0.0066 & -0.0255 & 0.0016 & 0.0044 & -0.0325 & -0.0082 & 0.0005 \\
\hline (2) Demographic changes & 0.0017 & -0.0012 & -0.0010 & 0.0100 & 0.0009 & -0.0001 & 0.0047 & -0.0002 & -0.0007 \\
\hline (a) Parental education & 0.0073 & 0.0010 & 0.0001 & 0.0171 & 0.0030 & 0.0009 & 0.0111 & 0.0024 & 0.0007 \\
\hline (b) No. Of children & -0.0060 & -0.0026 & -0.0013 & -0.0095 & -0.0026 & -0.0013 & -0.0076 & -0.0032 & -0.0016 \\
\hline \multirow[t]{2}{*}{ (c) Interaction } & 0.0004 & 0.0004 & 0.0002 & 0.0023 & 0.0005 & 0.0002 & 0.0011 & 0.0005 & 0.0003 \\
\hline & \multicolumn{3}{|c|}{ 1988-1995 } & \multicolumn{3}{|c|}{ 1995-2002 } & \multicolumn{3}{|c|}{ 1988-2002 } \\
\hline China as a whole & FGT(0) & FGT(1) & FGT(2) & FGT(0) & FGT(1) & FGT(2) & FGT(0) & FGT(1) & FGT(2) \\
\hline Actual change in poverty rate & -0.0149 & -0.0107 & -0.0092 & -0.1182 & -0.0353 & -0.0149 & -0.1332 & -0.0460 & -0.0241 \\
\hline (1) Economic changes & 0.0059 & -0.0051 & -0.0064 & -0.1030 & -0.0320 & -0.0136 & -0.1217 & -0.0416 & -0.0210 \\
\hline (a) Growth in mean adjusted income & -0.0893 & -0.0271 & -0.0118 & -0.1317 & -0.0383 & -0.0156 & -0.1650 & -0.0472 & -0.0200 \\
\hline (b) Change in income inequality & 0.0952 & 0.0220 & 0.0054 & 0.0287 & 0.0063 & 0.0020 & 0.0433 & 0.0056 & -0.0010 \\
\hline (2) Demographic changes & -0.0209 & -0.0057 & -0.0028 & -0.0152 & -0.0032 & -0.0013 & -0.0116 & -0.0044 & -0.0031 \\
\hline (a) Parental education & -0.0125 & -0.0032 & -0.0017 & -0.0039 & -0.0008 & -0.0003 & -0.0041 & -0.0019 & -0.0013 \\
\hline (b) No. of children & -0.0132 & -0.0037 & -0.0017 & -0.0138 & -0.0027 & -0.0010 & -0.0079 & -0.0026 & -0.0016 \\
\hline (c) Interaction & 0.0048 & 0.0013 & 0.0005 & 0.0025 & 0.0003 & 0.0000 & 0.0004 & 0.0000 & -0.0001 \\
\hline
\end{tabular}

Sources: Authors' calculations from HES 1995, HIES 2000, CHIP 1988, 1995 and 2002.

Note: Results for rural China are reported in appendix Table A2.

For definition of the FGT indices see note to Table 5. 
Table 7. The decomposition of percentage-point difference in the poverty rate: Crosscountry comparison of Bangladesh with China 1995 and 2000/2002 (rural regions and entire countries)

\section{Rural Regions of $\quad$ Entire Bangladesh and Bangladesh and China China}

\begin{tabular}{|c|c|c|c|c|c|c|}
\hline 1995 & FGT(0) & FGT(1) & FGT(2) & FGT(0) & FGT(1) & FGT(2) \\
\hline Actual difference in poverty rate & -0.2364 & -0.0877 & -0.0440 & -0.1950 & -0.0682 & -0.0334 \\
\hline (1) Economic differences & -0.1383 & -0.0620 & -0.0335 & -0.1126 & -0.0453 & -0.0233 \\
\hline (a) Difference in mean adjusted income & -0.2775 & -0.0992 & -0.0467 & -0.2460 & -0.0819 & -0.0375 \\
\hline (b) Difference in income inequality & 0.1392 & 0.0372 & 0.0132 & 0.1334 & 0.0366 & 0.0142 \\
\hline (2) Demographic differences & -0.0981 & -0.0257 & -0.0106 & -0.0824 & -0.0229 & -0.0101 \\
\hline (a) Parental education & -0.0704 & -0.0169 & -0.0064 & -0.0646 & -0.0171 & -0.0073 \\
\hline (b) No. of children & -0.0445 & -0.0134 & -0.0061 & -0.0412 & -0.0126 & -0.0057 \\
\hline (c) Interaction & 0.0167 & 0.0046 & 0.0019 & 0.0234 & 0.0067 & 0.0029 \\
\hline \multicolumn{7}{|l|}{ 2000/2002 } \\
\hline Actual difference in poverty rate & -0.2425 & -0.0827 & -0.0430 & -0.2144 & -0.0703 & -0.0361 \\
\hline (1) Economic differences & -0.2030 & -0.0697 & -0.0344 & -0.1926 & -0.0594 & -0.0283 \\
\hline (a) Difference in mean adjusted income & -0.2507 & -0.0746 & -0.0328 & -0.2439 & -0.0685 & -0.0301 \\
\hline (b) Difference in income inequality & 0.0477 & 0.0049 & -0.0016 & 0.0513 & 0.0091 & 0.0018 \\
\hline (2) Demographic differences & -0.0396 & -0.0130 & -0.0086 & -0.0218 & -0.0108 & -0.0077 \\
\hline (a) Parental education & -0.0295 & -0.0095 & -0.0059 & -0.0167 & -0.0081 & -0.0057 \\
\hline (b) No. of children & -0.0178 & -0.0052 & -0.0031 & -0.0104 & -0.0045 & -0.0031 \\
\hline (c) Interaction & 0.0078 & 0.0017 & 0.0004 & 0.0053 & 0.0019 & 0.0011 \\
\hline
\end{tabular}

Sources: Authors' calculations from HES 1995, HIES 2000, CHIP 1988, 1995 and 2002

Note:For definition of the FGT family of indices see note to Table 5. 
Table 8. The decomposition of percentage-point difference in the poverty rate: Crosscountry comparison between Bangladesh and Southwest China 1995 and 2000/2002

\begin{tabular}{|c|c|c|c|c|c|c|}
\hline \multirow[b]{2}{*}{1995} & \multicolumn{3}{|c|}{$\begin{array}{l}\text { Rural Bangladesh and Southwest rural } \\
\text { China }\end{array}$} & \multicolumn{3}{|c|}{ Entire Bangladesh and Southwest China } \\
\hline & FGT(0) & FGT(1) & FGT(2) & $\mathrm{FGT}(0)$ & FGT(1) & FGT(2) \\
\hline Actual difference in poverty rate & -0.0727 & -0.0484 & -0.0304 & -0.1227 & -0.0517 & -0.0283 \\
\hline (1) Economic differences & 0.0641 & 0.0005 & -0.0075 & -0.0165 & -0.0219 & -0.0152 \\
\hline (a) Difference in mean adjusted income & -0.0407 & -0.0176 & -0.0089 & -0.2019 & -0.0695 & -0.0323 \\
\hline (b) Difference in income inequality & 0.1048 & 0.0181 & 0.0014 & 0.1854 & 0.0476 & 0.0171 \\
\hline (2) Demographic differences & -0.1369 & -0.0488 & -0.0229 & -0.1062 & -0.0298 & -0.0132 \\
\hline (a) Parental education & -0.0802 & -0.0252 & -0.0110 & -0.0808 & -0.0217 & -0.0094 \\
\hline (b) No. of children & -0.0655 & -0.0284 & -0.0148 & -0.0613 & -0.0182 & -0.0081 \\
\hline (c) Interaction & 0.0089 & 0.0047 & 0.0029 & 0.0359 & 0.0101 & 0.0043 \\
\hline \multicolumn{7}{|l|}{$2000 / 2002$} \\
\hline Actual difference in poverty rate & -0.1748 & -0.0689 & -0.0397 & -0.1618 & -0.0594 & -0.0333 \\
\hline (1) Economic differences & -0.0961 & -0.0449 & -0.0276 & -0.1221 & -0.0461 & -0.0249 \\
\hline (a) Difference in mean adjusted income & -0.1208 & -0.0357 & -0.0160 & -0.2070 & -0.0602 & -0.0263 \\
\hline (b) Difference in income inequality & 0.0247 & -0.0092 & -0.0116 & 0.0849 & 0.0141 & 0.0014 \\
\hline (2) Demographic differences & -0.0787 & -0.0241 & -0.0122 & -0.0397 & -0.0133 & -0.0083 \\
\hline (a) Parental education & -0.0546 & -0.0170 & -0.0081 & -0.0299 & -0.0096 & -0.0058 \\
\hline (b) No. of children & -0.0409 & -0.0115 & -0.0055 & -0.0206 & -0.0062 & -0.0037 \\
\hline (c) Interaction & 0.0167 & 0.0044 & 0.0014 & 0.0108 & 0.0025 & 0.0012 \\
\hline
\end{tabular}

Sources: Authors' calculations from HES 1995, HIES 2000, CHIP 1988, 1995 and 2002.

Note: For definition of the FGT family of indices see note to Table 5. 


\section{Appendix Table A1. The Composition of Poverty in Bangladesh 1995 and 2000, and China 1988, 1995 and 2002. Percent}

\begin{tabular}{|c|c|c|c|c|c|c|c|c|c|c|c|c|c|c|}
\hline & \multicolumn{2}{|c|}{ Age } & \multicolumn{2}{|c|}{ Nationality } & \multicolumn{4}{|c|}{ No. of children } & \multicolumn{3}{|c|}{ Parental education } & \multicolumn{3}{|c|}{ region } \\
\hline & $<=6$ & $7-14$ & Han & Minority & 1 & 2 & 3 & 4 & One High & Other & Both Low & Coastal & Middle & Inland \\
\hline \multicolumn{15}{|c|}{ Bangladesh } \\
\hline Entire & 47.38 & 52.62 & & & 6.03 & 19.19 & 26.93 & 47.85 & 0.24 & 17.45 & 82.31 & 35.26 & 35.85 & 28.88 \\
\hline Urban & 45.06 & 54.94 & & & 3.69 & 18.18 & 29.64 & 48.48 & 0.70 & 18.12 & 81.18 & 38.21 & 30.70 & 31.09 \\
\hline $\begin{array}{l}\text { Rural } \\
2000\end{array}$ & 47.69 & 52.31 & & & 6.35 & 19.33 & 26.55 & 47.76 & 0.18 & 17.35 & 82.47 & 34.86 & 36.56 & 28.58 \\
\hline Entire & 44.98 & 55.02 & & & 6.41 & 21.11 & 28.82 & 43.66 & 0.19 & 23.36 & 76.45 & 30.71 & 36.30 & 32.99 \\
\hline Urban & 40.57 & 59.43 & & & 4.14 & 22.85 & 27.32 & 45.70 & 0.00 & 27.85 & 72.15 & 30.46 & 42.05 & 27.48 \\
\hline $\begin{array}{l}\text { Rural } \\
\text { China } \\
1988\end{array}$ & 45.71 & 54.29 & & & 6.79 & 20.82 & 29.07 & 43.32 & 0.22 & 22.61 & 77.17 & 30.76 & 35.34 & 33.90 \\
\hline Entire & 42.16 & 57.84 & 85.36 & 14.64 & 15.25 & 39.41 & 29.20 & 16.13 & 16.13 & 39.64 & 44.23 & 21.91 & 41.15 & 36.15 \\
\hline $\begin{array}{l}\text { Rural } \\
1995\end{array}$ & 42.50 & 57.50 & 85.28 & 14.72 & 15.18 & 39.21 & 29.45 & 16.17 & 16.36 & 39.28 & 44.36 & 21.68 & 40.98 & 37.33 \\
\hline Entire & 35.18 & 64.82 & 82.97 & 17.03 & 18.93 & 46.09 & 28.31 & 6.68 & 21.17 & 48.87 & 29.96 & 12.65 & 38.19 & 49.16 \\
\hline $\begin{array}{l}\text { Rural } \\
2002\end{array}$ & 34.88 & 65.12 & 82.55 & 17.45 & 18.99 & 45.82 & 28.64 & 6.55 & 21.18 & 47.92 & 30.90 & 12.44 & 37.56 & 50.00 \\
\hline Entire & 37.32 & 62.68 & 78.46 & 21.54 & 29.74 & 47.59 & 19.29 & 3.38 & 16.23 & 52.13 & 31.64 & 16.40 & 31.83 & 51.77 \\
\hline $\begin{array}{l}\text { Rural } \\
\text { SW Ch } \\
1988\end{array}$ & 37.05 & 62.95 & 78.32 & 21.68 & 29.29 & 47.90 & 19.42 & 3.40 & 16.01 & 52.15 & 31.85 & 16.50 & 31.72 & 51.78 \\
\hline Entire & 43.19 & 56.81 & 62.74 & 37.26 & 12.33 & 33.96 & 28.84 & 24.97 & 9.93 & 37.25 & 52.81 & & & \\
\hline $\begin{array}{l}\text { Rural } \\
1995\end{array}$ & 43.25 & 56.75 & 62.69 & 37.31 & 12.13 & 34.00 & 28.88 & 25.00 & 9.95 & 37.17 & 52.88 & & & \\
\hline Entire & 37.46 & 62.54 & 58.24 & 41.76 & 21.02 & 43.14 & 26.87 & 8.90 & 11.55 & 48.48 & 39.96 & & & \\
\hline $\begin{array}{l}\text { Rural } \\
2002\end{array}$ & 37.68 & 62.32 & 58.19 & 41.81 & 20.59 & 43.38 & 27.02 & 9.01 & 11.43 & 48.38 & 40.19 & & & \\
\hline Entire & 37.66 & 62.34 & 59.11 & 40.89 & 19.84 & 52.63 & 20.65 & 6.88 & 8.61 & 54.51 & 36.89 & & & \\
\hline Rural & 37.38 & 62.62 & 58.94 & 41.06 & 19.51 & 52.85 & 20.73 & 6.91 & 8.64 & 54.32 & 37.04 & & & \\
\hline
\end{tabular}

Sources: Authors’ calculations from HES 1995, HIES 2000, CHIP 1988, 1995 and 2002.

Note: The composition of urban child poverty has not been reported in the Table since the numbers of urban children living in poverty are found to be negligible in China (14, 22 and 3 in1988, 1995 and 2002, respectively).

Table A2. The decomposition of percentage-point change in poverty for rural China 1988 to 1995, 1995 to 2002 and 1988 to 2002.

\begin{tabular}{|c|c|c|c|c|c|c|c|c|c|}
\hline & \multicolumn{3}{|c|}{ 1988-1995 } & \multicolumn{3}{|c|}{ 1995-2002 } & \multicolumn{3}{|c|}{ 1988-2002 } \\
\hline & FGT(0) & FGT(1) & FGT(2) & FGT(0) & FGT(1) & FGT(2) & FGT(0) & FGT(1) & FGT(2) \\
\hline Actual change in poverty rate & -0.0139 & -0.0120 & -0.0109 & -0.1410 & -0.0433 & -0.0183 & -0.1549 & -0.0552 & -0.0292 \\
\hline (1) Economic changes & 0.0025 & -0.0081 & -0.0094 & -0.1225 & -0.0392 & -0.0169 & -0.1427 & -0.0527 & -0.0283 \\
\hline (a) Growth in mean adjusted income & -0.0912 & -0.0292 & -0.0129 & -0.1338 & -0.0405 & -0.0169 & -0.1824 & -0.0537 & -0.0229 \\
\hline (b) Change in income inequality & 0.0937 & 0.0211 & 0.0035 & 0.0113 & 0.0013 & 0.0000 & 0.0397 & 0.0010 & -0.0054 \\
\hline (2) Demograpł & -0.0164 & -0.0039 & -0.0015 & -0.0185 & -0.0041 & -0.0015 & -0.0122 & -0.0026 & -0.0010 \\
\hline (a) Parental education & -0.0082 & -0.0017 & -0.0008 & -0.0045 & -0.0009 & -0.0003 & -0.0009 & -0.0007 & -0.0005 \\
\hline (b) No. of children & -0.0108 & -0.0026 & -0.0009 & -0.0156 & -0.0036 & -0.0012 & -0.0105 & -0.0016 & -0.0004 \\
\hline (c) Interaction & 0.0025 & 0.0005 & 0.0002 & 0.0017 & 0.0003 & 0.0000 & -0.0008 & -0.0003 & -0.0001 \\
\hline
\end{tabular}

Sources: Authors’ calculations from HES 1995, HIES 2000, CHIP 1988, 1995 and 2002.

Note: For definition of the FGT family of indices see note to Table 5. 